\author{
Abstracta Iranica \\ Abstracta Iranica Revue bibliographique pour le domaine irano-aryen \\ Volume 40-41 | 2019 \\ Comptes rendus des publications de 2017-2018
}

\title{
Marcin Wagner. "The fire temple at Topaz Gala depe in southern Turkmenistan"
}

\section{Michele Minardi}

\section{(2) OpenEdition \\ 1 Journals}

\section{Electronic version}

URL: http://journals.openedition.org/abstractairanica/49881

DOI: 10.4000/abstractairanica.49881

ISBN: 1961-960X

ISSN: 1961-960X

Publisher:

CNRS (UMR 7528 Mondes iraniens et indiens), Éditions de l'IFRI

Electronic reference

Michele Minardi, "Marcin Wagner. "The fire temple at Topaz Gala depe in southern Turkmenistan"', Abstracta Iranica [Online], Volume 40-41 | 2019, document 16, Online since 30 December 2019, connection on 21 April 2021. URL: http://journals.openedition.org/abstractairanica/49881 ; DOI: https://doi.org/10.4000/abstractairanica.49881

This text was automatically generated on 21 April 2021

Tous droits réservés 
Marcin Wagner. "The fire temple at Topaz Gala depe in southern Turkmenistan"

Michele Minardi 


\section{REFERENCES}

Marcin Wagner. "The fire temple at Topaz Gala depe in southern Turkmenistan" in A Millennium of History. The Iron Age in southern Central Asia (2nd and 1st Millennia BC).

Proceedings of the conference held in Berlin (June 23-25, 2014). Dedicated to the memory of Viktor Ivanovich Sarianidi. Berlin, 2018, p. 333-351

1 With this short paper, Marcin Wagner presents recent findings of the Polish archaeological excavations at the site of Topaz Gala in modern southern Turkmenistan. The main structure unearthed at Topaz Gala is described by the author as a "fire temple". According to radiocarbon dating, and ceramic findings belonging to the Yaz II Central Asia material culture, the building is dated between the second half of the 10th century and the first half of the 8th century BC. Labeling the structure as a fire temple was based on the interpretation of some of its features. One was discovered in the structure's main pillared space: a square, mud-brick feature containing a circular clay element reddened by prolonged exposure to fire and associated with a "podium" of mud bricks built close to it. Another was a storage vessel found in a corner of the same room that was sunk into the floor and contained ashes. Two more such vessels were found upside-down inside the building. The monument has a rectangular shape and is encircled by a corridor (only in a first stage of construction?) that separates it from a fortified external wall strengthened by towers; this form is compared by the author to the Iron Age structures of Tillya-tepe, which were described by V.I. Sarianidi in a 1989 publication.

\section{AUTHORS}

\section{MICHELE MINARDI}

Centre of Classical and Oriental Archaeology, Moscow 